\title{
Insulin resistance in Type 2 (non-insulin-dependent) diabetic patients and their relatives is not associated with a defect in the expression of the insulin-responsive glucose transporter (GLUT-4) gene in human skeletal muscle
}

\author{
J.Eriksson ${ }^{1}$, L.Koranyi ${ }^{2}$, R.Bourey ${ }^{2}$, C. Schalin-Jäntti ${ }^{1}$, E. Widén ${ }^{1}$, M.Mueckler ${ }^{3}$, A.M.Permutt ${ }^{2}$ and L.C. Groop $^{1}$ \\ ${ }^{1}$ Fourth Department of Medicine and Department of Biochemistry, Helsinki University Hospital, Helsinki, Finland, \\ ${ }^{2}$ Metabolism Division, Department of Internal Medicine, and \\ ${ }^{3}$ Department of Cell Biology and Physiology, Washington University School of Medicine, St. Louis, Missouri, USA
}

Summary. To study whether insulin resistance in Type 2 (noninsulin-dependent) diabetes mellitus is due to a defect in the expression of the insulin-responsive glucose transporter gene (GLUT-4) in human skeletal muscle, we measured the level of GLUT-4 mRNA and (in some of the subjects) its protein in muscle biopsies taken from 14 insulin-resistant patients with Type 2 diabetes, 10 first-degree relatives of the diabetic patients and 12 insulin-sensitive control subjects. Insulin sensitivity was measured with a $+45 \mathrm{mU} \cdot \mathrm{m}^{2^{-1}} \cdot \mathrm{min}^{-1}$ euglycaemic insulin clamp in combination with indirect calorimetry and infusion of $\left[3-{ }^{3} \mathrm{H}\right] \mathrm{glucose}$. GLUT-4 mRNA was measured using a human GLUT-4 cDNA probe and GLUT-4 protein with a polyclonal antibody specific for the 15 amino acid carboxyterminal peptide. Both Type 2 diabetic patients and their relatives showed impaired stimulation of total-body glucose disposal by insulin compared with control subjects $(29.5 \pm 2.1$ and $34.0 \pm 4.8$ vs $57.9 \pm 3.1 \mu \mathrm{mol} \cdot \mathrm{kg}$ lean body mass ${ }^{-1} \cdot \mathrm{min}^{-1}$; $p<0.01$ ). This impairment in glucose disposal was primarily accounted for by a reduction in insulin-stimulated storage of glucose as glycogen $(13.0 \pm 2.4$ and $15.6 \pm 3.9$ vs $36.9 \pm$ $2.2 \mu \mathrm{mol} \cdot \mathrm{kg}$ lean body mass ${ }^{-1} \cdot \mathrm{min}^{-1} ; p<0.01$ ). The levels of GLUT-4 mRNA expressed both per $\mu \mathrm{g}$ of total RNA and per $\mu \mathrm{g}$ DNA, were higher in the diabetic patients compared with the control subjects $(116 \pm 25$ vs $53 \pm 10 \mathrm{pg} / \mu \mathrm{g}$
RNA and $177 \pm 35$ vs $112 \pm 29$ pg/ $\mu$ g DNA; $p<0.05, p<0.01$, respectively). The GLUT- 4 mRNA levels in the relatives were not significantly different from that observed in the control subjects $(90 \pm 16 \mathrm{pg} / \mu \mathrm{g}$ RNA and $117 \pm 23 \mathrm{pg} / \mu \mathrm{g}$ DNA; $p=\mathrm{NS}$ ). The GLUT-4 protein levels did not significantly differ between control subjects, diabetic patients and relatives $(494 \pm 85,567 \pm 133$ and $323 \pm 80 \mathrm{cpm} / 100 \mu \mathrm{g}$ protein). No correlation was observed between the level of GLUT-4 mRNA and its protein. However, the level of GLUT-4 mRNA and the rate of total-body glucose disposal correlated positively in the control group and in the relatives (both $p<0.05$ ) but not in the diabetic subjects. A positive correlation between the level of GLUT-4 protein and total-body glucose disposal was also observed in the control subjects $(r=0.759$; $p<0.05)$ and in the relatives $(r=0.794 ; p<0.01)$ but not in the diabetic subjects. We conclude that insulin resistance in Type 2 diabetes is not related to a defect in the expression of the GLUT-4 gene in skeletal muscle. Nevertheless, the levels of GLUT-4 mRNA and GLUT-4 protein are related to the rate of total-body glucose disposal in subjects with normal fasting glucose concentrations.

Key words: Type 2 (non-insulin-dependent) diabetes mellitus, insulin resistance, glucose transport, genes.
Insulin resistance is a characteristic feature of Type 2 (non-insulin-dependent) diabetes mellitus involving both the oxidative and non-oxidative pathway of glucose metabolism $[1,2]$. A defect proximal to these metabolic pathways such as impaired glucose transport into the cell has therefore been suggested to explain the insulin resistance in Type 2 diabetes [3,4]. Insulin-stimulated glucose transport in skeletal muscle is facilitated by an insulin-responsive glucose transporter (GLUT-4), which is encoded by a gene located on the short arm of chromosome 17 [5]. If insulin resistance in Type 2 diabetes is due to an inherited defect in glucose transport, this could be associated with a defect in the expression of the GLUT-4 gene in skeletal muscle of patients with Type 2 diabetes.
Patients with Type 2 diabetes are, however, characterized by hyperglycaemia, which can influence glucose transport [6]. Therefore, it is not always possible to differentiate that which is genetic and that which has developed secondary to chronic hyperglycaemia. One possibility to circumvent this problem is to study insulin-resistant first-degree relatives of patients with Type 2 diabetes, as these subjects are at greater risk of developing Type 2 diabetes [7-9].

To test this hypothesis, we have measured the insulinresponsive glucose transporter (GLUT-4) mRNA and its protein in muscle biopsies taken from insulin-resistant Type 2 diabetic patients and their first-degree relatives and compared them with the levels measured in insulin- 
Table 1. Clinical characteristics of subjects

\begin{tabular}{|c|c|c|c|}
\hline & $\begin{array}{l}\text { Control } \\
\text { subjects }\end{array}$ & $\begin{array}{l}\text { Type } 2 \text { (non- } \\
\text { insulin-depen- } \\
\text { dent) diabetic } \\
\text { patients }\end{array}$ & Relatives \\
\hline$\overline{n(\mathrm{female} / \mathrm{male})}$ & $12(5 / 7)$ & $14(7 / 7)$ & $10(6 / 4)$ \\
\hline Age (years) & $44 \pm 7$ & $60 \pm 2^{a}$ & $51 \pm 2$ \\
\hline $\begin{array}{l}\text { Body mass } \\
\text { index }\left(\mathrm{kg} / \mathrm{m}^{2}\right)\end{array}$ & $23.4 \pm 0.6$ & $29.7 \pm 1.2^{\mathrm{b}}$ & $27.0 \pm 1.1$ \\
\hline Lean body mass $(\mathrm{kg})$ & $49 \pm 2$ & $47 \pm 3$ & $51 \pm 4$ \\
\hline $\begin{array}{l}\text { Fasting plasma glucose } \\
(\mathrm{mmol} / \mathrm{l})\end{array}$ & $5.0 \pm 0.1$ & $10.5 \pm 0.9^{c}$ & $5.3 \pm 0.2$ \\
\hline Glycohaemoglobin (\%) & $5.9 \pm 0.2$ & $9.9 \pm 0.5^{c}$ & $6.1 \pm 0.3$ \\
\hline $\begin{array}{l}\text { Fasting serum insulin } \\
(\mu \mathrm{U} / \mathrm{ml})\end{array}$ & $5 \pm 1$ & $13 \pm 2^{b}$ & $10 \pm 2$ \\
\hline
\end{tabular}

Values are mean \pm SEM. ${ }^{a} p<0.05,{ }^{b} p<0.01$ vs control subjects and ${ }^{\circ} p<0.01$ vs relatives and control subjects

sensitive control subjects. The data indicate that the GLUT-4 mRNA and GLUT-4 protein levels are normal in these subjects despite severe degree of insulin resistance, thereby challenging the view that a genetic defect resulting in altered levels of glucose transporters could be the cause of insulin resistance in Type 2 diabetes.

\section{Subjects and methods}

\section{Subjects}

Fourteen Type 2 diabetic patients, 10 first-degree relatives of patients with Type 2 diabetes and 12 healthy control subjects without a family history of diabetes participated in the study. The clinical characteristics of the subjects are given in Table 1. Informed consent was obtained from all subjects, and the study protocol was approved by the Ethical Committee of the Helsinki University Hospital.

\section{Methods}

Insulin sensitivity was measured by a euglycaemic hyperinsulinaemic clamp in combination with indirect calorimetry and infusion of [ $\left.3-{ }^{3} \mathrm{H}\right]$ glucose [10]. After three baseline samples were obtained for measurement of glucose and insulin, a primed constant infusion of short-acting human insulin (Actrapid; Novo Industry, Copenhagen, Denmark) was administered at a rate of $45 \mathrm{mU} \cdot \mathrm{m}^{2-4} \cdot \min ^{-1}$ for $2 \mathrm{~h}$. The plasma glucose concentration was determined at 5 min intervals, and an infusion of $20 \%$ glucose was adjusted to maintain a constant plasma glucose concentration. In the diabetic patients, whose plasma glucose concentrations were initially high, no glucose was infused until the plasma glucose concentration had declined to $5.5 \mathrm{mmol} / \mathrm{l}$. The clamp was applied for $2 \mathrm{~h}$ in the control subjects and relatives, whereas it was applied for a mean ( \pm SEM) of $138( \pm 7)$ min to achieve the desired goal in the diabetic patients. At a constant plasma glucose concentration, the amount of glucose required to maintain euglycaemia equals the value for total-body glucose metabolism, provided there is no entry of glucose from the liver. The steady-state serum insulin concentrations achieved during the last $60 \mathrm{~min}$ of the clamp in Type 2 diabetic patients, relatives and control subjects were $85 \pm 3,84 \pm 6$ and $81 \pm 5 \mu \mathrm{U} / \mathrm{ml}$, respectively. The coefficient of variation in steady-state plasma glucose and insulin concentrations during the last $60 \mathrm{~min}$ of the insulin clamps was $4 \pm 2 \%$ and $7 \pm 2 \%$, respectively.

Hepatic glucose production was measured by the isotope dilution technique using $\left[{ }^{3}{ }^{3} \mathrm{H}\right]$ glucose (Amersham, Amersham, UK) administered at a primed $(25 \mu \mathrm{Ci}$; this dose was increased if fasting plasma glucose was high) constant infusion rate of $0.25 \mu \mathrm{Ci} / \mathrm{min}$ for $150 \mathrm{~min}$. Blood samples were obtained for determination of insulin levels and $\left[3-{ }^{3} \mathrm{H}\right]$ glucose specific activity at baseline and at $15-\mathrm{min}$ intervals during the clamp. Indirect calorimetry was employed in the basal state and during the last $60 \mathrm{~min}$ of the insulin clamp to estimate net rates of glucose and lipid oxidation [11]. A computerized, opencircuit system was used to measure gas exchange through a transparent plastic canopy (Deltatrac; Datex, Helsinki, Finland). The monitor has a precision of $2.5 \%$ for oxygen consumption and of $1.0 \%$ for carbon dioxide production. Protein oxidation was calculated from the urinary urea nitrogen excretion obtained before and during the insulin clamp and corrected for urea clearance.

Lean body mass (LBM) was determined using the tritiated water dilution technique [12].

\section{Muscle biopsies}

A percutaneous muscle biopsy $(20-40 \mathrm{mg}$ ) was taken from the vastus lateralis muscle under local anaesthesia ( $1 \%$ lidocaine) using a Bergström needle [13]. The muscle specimens were immediately placed into liquid nitrogen and kept frozen at $-70^{\circ} \mathrm{C}$ until analysed.

\section{Assays}

The plasma glucose concentrations were measured by the glucose oxidase method on a Beckman glucose analyser II (Beckman Instruments, Fullerton, Calif., USA). Glycohaemoglobin concentrations in blood were measured by high pressure liquid chromatography (range 5-7\%). Serum insulin was measured by a double-antibody radioimmunoassay (Pharmacia, Uppsala, Sweden). $\left[3-{ }^{3} \mathrm{H}\right]$ glucose specific activity was measured in duplicate on supernatants of $1 \mathrm{~mol} / \mathrm{l}$ perchloric acid extracts of plasma samples after evaporation of radiolabelled water.

Quantitation of GLUT-4 $m R N A$. Total tissue RNA was extracted using a modified guanidine thiocyanate (GuSCN) water saturated phenol extraction method [14]. Samples were homogenized in $4 \mathrm{~mol} / \mathrm{h} \mathrm{GuSCN}$ containing octylphenolethylenoxid detergent (nonident P-40; Sigma Chemical Co., St. Louis, Mo., USA) and multiple phenol/chloroform/isoamylalcohol extractions were applied. The quantity and quality of RNA samples were determined by absorbance at 260 and $280 \mathrm{~nm}$; the values for the $260 / 280$ ratio were over 2.0 in each sample.

Quantitation of GLUT-4 mRNA was performed by dot blot analysis utilizing human GLUT-4 cDNA probe. Human GLUT-4 cDNA was isolated from a jejunal cDNA library [15] using rat GLUT-4 as the probe [16]. Sequence analysis indicated that the 1.7 kilobase human cDNA insert was identical to the lambda HJHT-3 clone previously described [17]. This clone contains a 260 base pair intron at the $3^{\prime}$ end. The cDNA was subcloned into a Bluescript SK + plasmid (Stratagene, La Jolla, Calif., USA). Transcription of synthetic mRNA standard and ${ }^{32} \mathrm{P}$-labelled cRNA with T3 or T7 RNA polymerase was performed according to the manufacturer's instructions. Aliquots of total RNA $(0.5-10 \mu \mathrm{g})$ and dilutions of synthetic mRNA $(0.5-1000 \mathrm{pg})$ and cDNA (1-1000 pg) as standards were dissolved in $15 \%$ formaldehyde/10 $\times$ standard saline citrate (SSC) and blotted onto Nytran (Schleicher and Schuell Inc., Keene, $\mathrm{NH}$, USA) membranes. Membranes were hybridized for $16-18 \mathrm{~h}$ at $60^{\circ} \mathrm{C}$ in a $50 \%$ formamide, $5 \times$ SSPE $(0.75 \mathrm{~mol} / \mathrm{l} \mathrm{NaCl}, 5 \mathrm{mmol} / \mathrm{l}$ EDTA, $50 \mathrm{mmol} / / \mathrm{NaH}_{2} \mathrm{PO}_{4}, \mathrm{pH} 7.4$ ), $5 \times$ Denhardts', $0.1 \%$ sodium dodecyl sulphate (SDS), $200 \mu \mathrm{g} / \mathrm{ml}$ salmon sperm DNA and then washed at $65^{\circ} \mathrm{C}$ in $0.1 \times \mathrm{SSC}, 0.1 \% \mathrm{SDS}$, according to the recommendations of the vendor. Blots were exposed to Kodak XAR5 film at $-70^{\circ} \mathrm{C}$ using intensifying screens (Cronex Lightening Plus; E. I. Dupont de Nemours Co., Wilmington, Del., USA). The amount of mRNA present in each sample determined in duplicate, was measured by densitometric analysis, comparing the intensity of the sample dot with standard dots. Autoradiographs were developed for various periods of time so that the intensity of the unknown samples was within the linear range of standards. The DNA concentrations in homogenized tissue samples were determined by fluorometer 
Table 2. Insulin-stimulated glucose metabolism

\begin{tabular}{lclc}
\hline & $\begin{array}{l}\text { Control } \\
\text { subjects }\end{array}$ & $\begin{array}{l}\text { Type 2(non- } \\
\text { insulin-de- } \\
\text { pendent) dia- } \\
\text { betic patients }\end{array}$ \\
\hline $\begin{array}{l}\text { Glucose disposal } \\
\left(\mu \mathrm{mol} \cdot \mathrm{kg} \mathrm{LBM}^{-1} \cdot \mathrm{min}^{-1}\right)\end{array}$ & $57.9 \pm 3.1$ & $29.5 \pm 2.1^{\mathrm{a}}$ & $34.0 \pm 4.8^{\mathrm{a}}$ \\
$\left.\begin{array}{l}\text { Glucose oxidation } \\
(\mu \mathrm{mol} \cdot \mathrm{kg} \mathrm{LBM}\end{array} \mathrm{min}^{-1}\right)$ & $21.0 \pm 1.4$ & $16.6 \pm 1.5$ & $18.4 \pm 1.9$ \\
$\begin{array}{l}\text { Non-oxidative glucose } \\
\text { metabolism }\end{array}$ & $36.9 \pm 2.2$ & $13.0 \pm 2.4^{\mathrm{a}}$ & $15.6 \pm 3.9^{\mathrm{a}}$ \\
$\left(\mu \mathrm{mol} \cdot \mathrm{kg} \mathrm{LBM}^{-1} \cdot \mathrm{min}^{-1}\right)$ & & & \\
\hline
\end{tabular}

Values are mean \pm SEM. ${ }^{a} p<0.001$ vs control subjects.

LBM, lean body mass

Table 3. GLUT- 4 mRNA and protein concentrations in muscle biopsies taken from healthy control subjects, patients with Type 2 (non-insulin-dependent) diabetes and first-degree relatives of patients with Type 2 diabetes

\begin{tabular}{|c|c|c|c|}
\hline & $\begin{array}{l}\text { Control } \\
\text { subjects } \\
(n=7)\end{array}$ & $\begin{array}{l}\text { Type } 2 \text { diabe- } \\
\text { tic patients } \\
(n=7)\end{array}$ & $\begin{array}{l}\text { Relatives } \\
(n=10)\end{array}$ \\
\hline 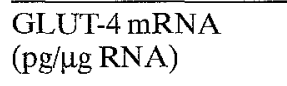 & $53 \pm 10$ & $116 \pm 25^{a}$ & $90 \pm 16$ \\
\hline 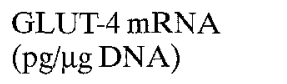 & $112 \pm 29$ & $177 \pm 35^{\mathrm{b}}$ & $117 \pm 23$ \\
\hline $\begin{array}{l}\text { GLUT-4 protein } \\
(\mathrm{cpm} / 100 \mu \mathrm{g} \text { protein) }\end{array}$ & $494 \pm 85$ & $567 \pm 133$ & $323 \pm 80$ \\
\hline
\end{tabular}

Values are mean \pm SEM. ${ }^{\mathrm{a}} p<0.05,{ }^{\mathrm{b}} p<0.01$ vs control subjects

(DNA fluorometer; Model TKO 100; Hoefer Scientific Instrument, San Francisco, Calif., USA) using the Hoechst 33258 dye. Coefficient of variation for GLUT-4 mRNA expressed per total RNA and DNA were $7 \%$ and $8 \%$, respectively.

Immunoblotting. Muscle from seven control, seven diabetic subjects and ten relatives was homogenized with a polytron (Brinkman, Westbury, NY, USA) on ice at high speed for $45 \mathrm{~s}$ in HES buffer ( $20 \mathrm{mmol} / 1$ Hepes, $1 \mathrm{mmol} / \mathrm{l}$ EDTA, $250 \mathrm{mmol} / 1$ sucrose, $\mathrm{pH} 7.4$, 1:20 weight/volume). The protein concentration was determined by a modification of the method of Lowry [18] and samples were subjected to SDS-polyacrylamide gel electrophoresis. Protein was electrophoretically transferred (Polyblot; ABN, Hayward, Calif., USA) to nitrocellulose paper. Nitrocellulose sheets were incubated with phosphate-buffered saline ( $\mathrm{pH} \mathrm{7.4)} \mathrm{containing} 50 \mathrm{mg} / \mathrm{ml}$ of powdered milk (Carnation Co., Los Angeles, Calif., USA) for $60 \mathrm{~min}$ at $22^{\circ} \mathrm{C}$ and thereafter with a polyclonal antibody specific for the 15 amino acid GLUT-4 carboxy-terminus peptide (F349). After washing, blots were incubated with ${ }^{125}$ I-labelled protein A (Amersham Corp., Arlington Heights, Ill., USA). Quantitation was performed by excising labelled bands and counting in a gamma counter (Packard Instrument Co., Downers Grove, Ill., USA). Equal areas away from the band of interest were excised and analysed to establish background.

\section{Calculations}

Basal hepatic glucose production was calculated by dividing the [3$\left.{ }^{3} \mathrm{H}\right]$ glucose infusion rate by the steady-state plateau of $\left[3-{ }^{3} \mathrm{H}\right]$ glucose specific activity during the last $30 \mathrm{~min}$ of the basal tracer infusion period. After administration of insulin and glucose, a non-steadystate condition in glucose specific activity exists, and the rate of glucose appearance was calculated by a non-steady-state equation [19]. The infusion rate of cold glucose was integrated over 20 min inter- vals and subtracted from the total rate of glucose appearance to obtain hepatic glucose production rate. This model is known to produce negative estimates of hepatic glucose production at high rates of glucose disposal. Negative numbers were occasionally observed in the control subjects and first-degree relatives during the insulin clamp. Total-body glucose metabolism was calculated by adding the mean rate of hepatic glucose production (if a positive number) during the last $60 \mathrm{~min}$ of the insulin clamp to the mean rate of glucose infusion during the same period. Non-oxidative glucose metabolism i.e. mainly glycogen synthesis in skeletal muscle [20] was calculated as the difference between total-body glucose metabolism and glucose oxidation as determined by indirect calorimetry.

Net glucose and lipid oxidation rates were calculated from indirect calorimetric measurements. The constants used to calculate glucose, lipid and protein oxidation have been specified by Ferrannini [11].

\section{Statistical analysis}

All values are expressed as mean \pm SEM. Differences between group means were tested with analysis of variance and analysis of covariance with age as covariate using a BMDP computer program [21]. Scheffe's method was used for multiple comparisons between group means. Correlations were tested with linear regression analysis.

\section{Results}

Insulin-stimulated glucose disposal was reduced by $49 \%$ and $41 \%$ in Type 2 diabetic patients and first-degree relatives, respectively, as compared to control subjects $(p<0.001$, Table 2$)$. Since there was no difference in insulin-stimulated glucose oxidation between the groups, the impairment in glucose disposal in the insulin-resistant subjects was almost completely accounted for by impaired non-oxidative glucose metabolism $(p<0.001$ vs control subjects, Table 2).

The levels of GLUT-4 mRNA expressed both per $\mu \mathrm{g}$ of total RNA $(p<0.05)$ and per $\mu$ g of DNA $(p<0.01)$ were higher in the diabetic subjects compared to the control subjects. The levels in the relatives were intermediate between these two groups (Table 3). There was no correlation between the GLUT-4 mRNA levels and the rate of total-body glucose disposal when all subjects were analysed together $(r=-0.276)$. However, the GLUT-4 mRNA correlated positively with the rate of glucose disposal in control subjects $(r=0.598 ; p<0.05)$ and relatives $(r=0.587 ; p<0.05)$ but not in the diabetic patients $(r=0.127 ; p=\mathrm{NS})$.

The GLUT-4 protein concentrations did not significantly differ between control subjects, relatives and diabetic subjects (Table 3 ). The levels of GLUT-4 protein correlated positively with the rate of glucose disposal in the control subjects $(r=0.759 ; p<0.05)$ and in the relatives $(r=0.794 ; p<0.05)$, whereas there was an inverse correlation in the diabetic subjects $(r=-0.706 ; p<0.05)$. When the GLUT-4 protein data from all the groups were combined, a weak positive correlation with the rate of glucose disposal was observed $(r=0.426 ; p<0.05)$ (Fig. 1). There was no significant correlation between the levels of GLUT-4 mRNA/ $\mu \mathrm{g}$ RNA and the GLUT-4 protein or between the GLUT-4 mRNA/ $\mu \mathrm{g}$ DNA and the GLUT-4 protein levels in any of the groups studied. 


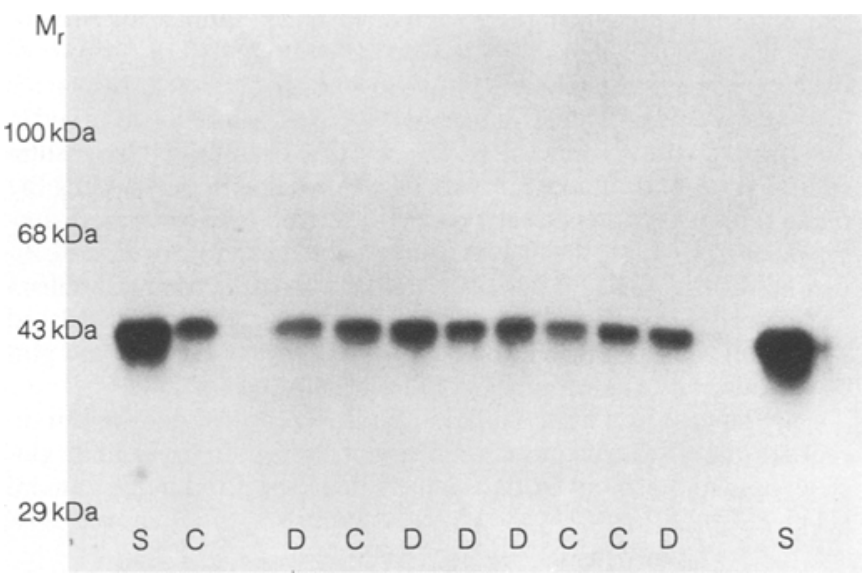

Fig. 1. Representative Western blot. $100 \mu \mathrm{g}$ total muscle protein per lane from control (C), diabetic (D), or rat soleus standard (S). $\mathrm{kDa}$, kilodalton

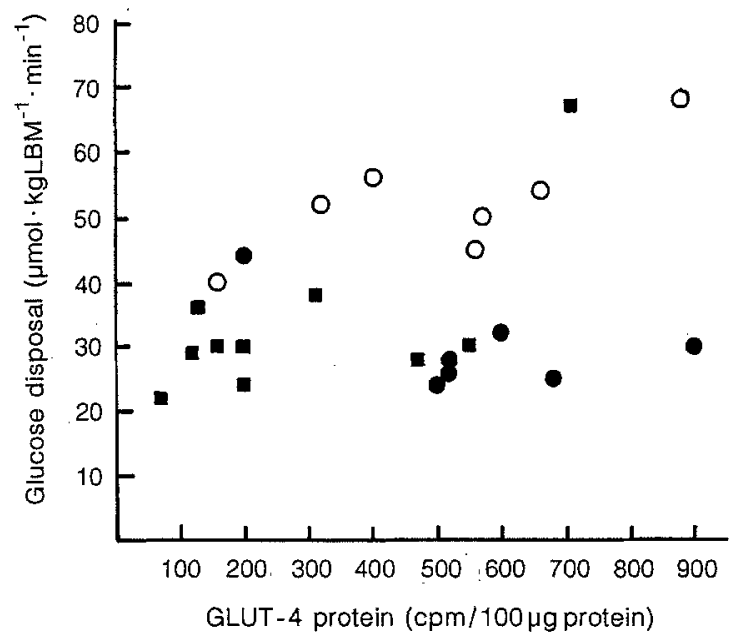

Fig. 2. Relationship between rate of insulin-stimulated glucose disposal and GLUT-4 protein concentrations in healthy control subjects ( $O, r=0.759 ; p<0.05)$, Type 2 (non-insulin-dependent) diabetic patients $(\bullet, r=-0.706 ; p<0.05)$ and relatives of patients with Type 2 diabetes $(\mathbf{\square}, r=0.794, p<0.01$ ). All subjects, $r=0.426$; $p<0.05$. LBM, lean body mass

\section{Discussion}

Insulin-mediated glucose uptake into insulin-sensitive cells, i.e. adipocytes, heart and muscle cells, is mediated by specific insulin-responsive glucose transporters. After insulin stimulation, the glucose transporters translocate from intracellular membrane vesicles to the plasma membrane [22-24]. In rat adipocytes insulin stimulation produces a ten-fold increase in the transporters at the plasma membrane [24]. Given this knowledge, impaired insulinstimulated glucose transport in skeletal muscle has provided an attractive hypothesis to explain peripheral insulin resistance in Type 2 diabetes [3, 4]. This hypothesis has been supported by studies showing decreased glucose transporter number and intrinsic activity in adipocytes from streptozotocin-diabetic rats $[25,26]$ and patients with Type 2 diabetes [3]. In addition, a decrease in the pool of intracellular glucose transporters has been related to a decrease in the expression of the insulin-responsive glucose transporter gene in adipocytes from streptozotocin-diabetic rats [27]. Insulin treatment has been able to normalize the GLUT-4 mRNA content in adipocytes from these animals [25].

Extrapolating data from studies in insulin-deficient streptozotocin-diabetic rats to patients with Type 2 diabetes may, however, be dangerous. Furthermore, it is not known whether changes observed in adipocytes really reflect changes in human skeletal muscle. The major part of glucose uptake occurs in skeletal muscle whereas adipocytes contribute less than $5 \%$ [28].

Therefore, only studies in skeletal muscle of insulinresistant patients with Type 2 diabetes can answer the question whether insulin resistance in Type 2 diabetes is related to a defect in glucose transport. We addressed this question by measuring the concentration of GLUT-4 mRNA and its protein in muscle biopsies from both insulin-resistant Type 2 diabetic subjects and their firstdegree relatives, and comparing these to insulin-sensitive control subjects. The Type 2 diabetic patients showed a $49 \%$ reduction in total glucose disposal, which was primarily accounted for by reduced storage of glucose as glycogen. In contrast to data in streptozotocin-diabetic rats $[22,27]$ we did not observe reduced expression of GLUT-4 mRNA or its protein in these Type 2 diabetic patients. On the contrary, the GLUT- 4 mRNA concentrations were slightly higher in the diabetic patients than in the control subjects. Of note, the diabetic subjects had both fasting hyperglycaemia and hyperinsulinaemia.

Chronic hyperglycaemia can induce insulin resistance and impaired glucose transport in adipocytes from diabetic rats $[29,30]$. Normalizing of hyperglycaemia by phlorizin can reverse both insulin resistance and impaired glucose transport in these animals [31]. It is, therefore, unlikely that chronic hyperglycaemia would stimulate glucose transport. Preliminary data suggest that acute hyperinsulinaemia created during a euglycaemic clamp increases levels of GLUT-4 mRNA in skeletal muscle [32]. One could therefore assume, that chronic hyperinsulinaemia as observed in the diabetic subjects resulted in the slight increase observed in GLUT-4 mRNA levels. To circumvent the problem with chronic hyperglycaemia, we also examined insulin-resistant normoglycaemic first-degree relatives of patients with Type 2 diabetes. These subjects represent a high risk group for development of Type 2 diabetes [7--9] and they presented almost the same degree of insulin resistance as the Type 2 diabetic patients. Expression of the GLUT-4 mRNA and its protein was not significantly altered in the relatives, challenging the view that insulin resistance in these subjects is due to a genetic defect in the expression of the GLUT-4 gene in skeletal muscle. On the other hand, in keeping with previous data, the GLUT-4 protein levels in the control subjects correlated positively with the rate of total-body glucose disposal [32]. A strong positive correlation was also observed between the GLUT-4 protein levels and the rate of glucose metabolism in the relatives. Although this correlation suggests that glucose uptake and transport are related under physiological conditions, the negative correlation between the GLUT-4 protein levels and glucose disposal in 
the Type 2 diabetic subjects suggests that other factors must be responsible for manifestation of insulin resistance in Type 2 diabetes. Two recent papers have reported normal concentrations of the GLUT-4 protein in skeletal muscle from patients with Type 2 diabetes $[33,34]$. In the present study, the individual subjects were shown to be insulin resistant by insulin clamp measurements. While the number of determinations is small, and larger sample size may reveal small differences in levels, taken together, the data do not support a role for a genetic defect in levels of GLUT-4 products in the pathogenesis of insulin resistance in Type 2 diabetes. These data do not exclude, however, the possibility of an inherited defect in the GLUT-4 gene which could result in altered GLUT-4 function.

Acknowledgements. This study was supported by grants from the $\mathrm{Si}$ grid Jusélius Foundation, the Perklén Foundation, the Nordisk Insulin Foundation and Finska Läkaresällskapet.

\section{References}

1. Groop LC, Bonadonna RC, DelPrato Set al. (1989) Glucose and free fatty acid metabolism in non-insulin dependent diabetes mellitus. Evidence for multiple sites of insulin resistance. J Clin Invest 84: 205-213

2. Golay A, DeFronzo RA, Ferrannini E et al. (1988) Oxidative and non-oxidative glucose metabolism in non-obese Type 2 (non-insulin-dependent) diabetic patients. Diabetologia 31:585-591

3. Garvey WT, Hueckstedt TP, Matthaei S, Olefsky JM (1988) Role of glucose transporters in the cellular insulin resistance of type II non-insulin dependent diabetes mellitus. J Clin Invest 81: 15281536

4. DeFronzo RA (1988) The triumvirate: $\beta$-cell, muscle, liver. A collusion responsible for NIDDM. Diabetes 37: 667-687

5. Bell GI, Murray JC, Nakamura Y et al. (1989) Polymorphic human insulin-responsive glucose transporter gene on chromo some 17p13. Diabetes 38: 1072-1075

6. Yki-Järvinen H (1990) Acute and chronic effects of hyperglycaemia on glucose metabolism. Diabetologia 33: 579-585

7. Lillioja S, Mott DM, Howard BV et al. (1988) Impaired glucose tolerance as a disorder of insulin action. Longitudinal and crosssectional studies in Pima Indians. N Engl J Med 318: 1217-1225

8. Eriksson J, Franssila-Kallunki A, Ekstrand A et al. (1989) Early metabolic defects in persons at increased risk for non-insulin dependent diabetes mellitus. N Engl J Med 321: 337-343

9. Köbberling J, Tillil H, Lorenz HJ (1985) Genetics of type 2Aand type 2B-diabetes mellitus. Diab Res Clin Pract 11 [Suppl 1]: S311 (Abstract)

10. DeFronzo RA, Tobin JD, Andres J (1979) Glucose clamp technique: a method for quantifying insulin secretion and resistance. Am J Physiol 237: E214-E223

11. Ferrannini $\mathrm{E}$ (1988) The theoretical basis of indirect calorimetry: a review. Metabolism 37:287-301

12. Coleman TG, Manning RD Jr, Norman RA Jr, Guyton AC (1972) Dynamics of water-isotope distribution. Am J Physiol 223: $1371-1375$

13. Hultman E (1967) Muscle glycogen in man determined in needle biopsy specimens. Scand J Clin Lab Invest 19: 209-217

14. Koranyi L, James D, Mueckler M, Permutt A (1990) Glucose transporter levels in spontaneously obese $(\mathrm{db} / \mathrm{db})$ insulin resistant mice. J Clin Invest 85: 962-967

15. Green F, Edwards Y, Huari HP et al. (1987) Isolation of a cDNA probe for human jejunal brush border hydrolase, sucrose-isomaltase, and assignment of the gene locus to chromosome 3. Gene 57:101-110

16. James DE, Strube M, Mueckler ME (1989) Molecular cloning and characterization of an insulin-regulatable giucose transporter. Nature 338: 83-87
17. Fukumoto H, Kyano T, Buse JB et al. (1989) Cloning and characterization of the major insulin responsive glucose transporter expressed in human skeletal muscle and other insulin responsive tissues. J Biol Chem 264: 776-779

18. Peterson GL (1977) A simplification of the protein assay method of Lowry et al which is more generally applicable. Anal Biochem 83: $346-356$

19. Radziuk J, Norwich KH, Vranic M (1978) Experimental validation of measurements of glucose turnover in nonsteady state. Am J Physiol 234: E84-E93

20. Shulman G, Rothman D, Jue T, Stein P, DeFronzo RA, Shulman $R(1990)$ Quantitation of muscle glycogen synthesis in normal subjects and subjects with non-insulin dependent diabetes by ${ }^{13} \mathrm{C}$ nuclear magnetic resonance spectroscopy. N Engl J Med 322: 223-228

21. Dixon WJ (ed) (1988) BMDP statistical software manual. University of California Press, Berkeley

22. Kahn BB, Flier JS (1990) Regulation of glucose transporter gene expression in vitro and in vivo. Diab Care 13: 548-564

23. Simpson IA, Cushman SW (1986) Hormonal regulation of mammalian glucose transport. Annu Rev Biochem 55: 1059-1089

24. James DE, Brown R, Navarro J, Pilch PF (1988) Insulin-regulatable tissues express a unique insulin sensitive glucose transport protein. Nature (Lond) 333: 183-185

25. Kahn BB, Cushman SW (1987) Mechanism for markedly hyperresponsive insulin-stimulated glucose transport activity in adipose cells from insulin-treated streptozotocin diabetic rats: evidence for increased glucose transporter intrinsic activity. J Biol Chem 262: 5118-5124

26. Karnieli E, Armoni M, Cohen P, Kanter Y, Rafaeloff R (1987) Reversal of insulin resistance in diabetic rat adipocytes by insulin therapy: restoration of a pool of glucose transporters and enhancement of glucose transport activity. Diabetes 36: 925-931

27. Berger J, Biswas C, Vicario P, Strout HV, Saperstein R, Pilch PF (1989) Decreased expression of the insulin-responsive glucose transporter in diabetes and fasting. Nature (Lond) 340: 70-73

28. Mårin P, Rebuffé-Scrive M, Smith U, Björntorp P (1987) Glucose uptake in human adipose tissue. Metabolism 36: 1152-1160

29. Rossetti L, Smith D, Shulman G, Papachristou D, DeFronzo RA (1978) Correction of hyperglycemia with phlorozine normalizes tissue sensitivity to insulin in diabetic rats. J Clin Invest 79: 1510 1515

30. Garvey TW, Huecksteadt TP, Birnbaum MJ (1989) Pretranslational suppression of an insulin-responsive glucose transporter in rats with diabetes mellitus. Science 245: 60-63

31. Kahn BB (1990) Normalization of blood glucose in diabetic rats with phlorizin treatment reverses insulin resistant glucose transport in adipose cells without restoring glucose transporter gene expression. Diabetes 39 [Suppl 1]: 10A (Abstract)

32. Vuorinen-Markkola H, Koivisto V, Koranyi L et al. (1991) A glucose-flux independent defect in insulin action on GluT-4 gene expression in skeletal muscle characterizes insulin resistant Type 1 Diabetes. Diabetes 40 [Suppl 1]: 157A (Abstract)

33. Pedersen O, Bak J, Andersen P et al. (1990) Evidence against altered expression of GLUT1 or GLUT4 in skeletal muscle of patients with obesity or NIDDM. Diabetes 39: 865-870

34. Handberg A, Vaag A, Damsbo P, Beck-Nielsen H, Vinten J (1990) Expression of insulin regulatable glucose transporters in skeletal muscle from Type 2 (non-insulin-dependent) diabetic patients. Diabetologia 33: 625-627

Received: 20 December 1990

and in revised form: 30 September 1991

Dr. L.C. Groop

Fourth Department of Medicine

Helsinki University Hospital

Unioninkatu 38

SF-00170 Helsinki

Finland 